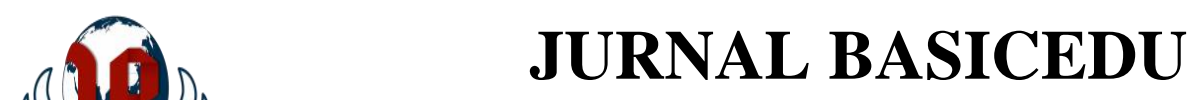

Volume 5 Nomor 3 Tahun 2021 Halaman 1356 - 1364

Research \& Learning in Elementary Education https://jbasic.org/index.php/basicedu

\title{
Peran Guru dalam Pembelajaran Membaca dan Menulis Melalui Gerakan Literasi di Sekolah Dasar
}

\author{
Vira Safitri $^{1 凶}$, Febrina Dafit $^{2}$ \\ Pendidikan Guru Sekolah Dasar, Universitas Islam Riau ${ }^{1,2}$ \\ E-mail: Virasafitri75@gmail.com ${ }^{1}$, febrinadafit@gmail.com²
}

\begin{abstract}
Abstrak
Penelitian ini bertujuan untuk mendeskripsikan peran guru dalam pembelajaran membaca dan menulis di sekolah dasar. Penelitian ini dilaksanakan di SDN 151 Pekanbaru yang terhitung pada bulan Februari hingga Maret. Penelitian ini menggunakan metode kualitatif yang bersifat deskriptif. Subjek yang digunakan pada penelitian ini adalah kepala sekolah, guru dan siswa SDN 151 Pekanbaru. Teknik pengumpulan data yang digunakan dalam penelitian ini berupa wawancara dan dokumentasi. Hasil dari penelitian ini adalah Gerakan Literasi Sekolah di SDN 151 Pekanbaru khususnya kelas 4 terdiri atas beberapa program seperti membaca Alquran, membaca buku, perpustakaan, dan pojok literasi. Peran guru dalam membaca melalui GLS yaitu membimbing siswa dalam menemukan buku bacaan yang tepat, sebagai fasilitator dengan memberikan pelayanan untuk memudahkan dalam proses pembelajaran, sebagai motivator bagi siswa dalam belajar. Sedangkan peran guru dalam menulis yaitu melatih siswa dalam menciptakan suatu karya tulis, sebagai fasilitator dengan memberikan rasa senang pada siswa, dan mengevaluasi hasil kerja siswa seperti kegiatan menulis puisi, pantun dan meringkas.
\end{abstract}

Kata Kunci: Guru, Membaca dan menulis, GLS.

Abstract

This study aims to describe the role of teachers in learning to read and write in elementary schools. This research was conducted at SDN 151 Pekanbaru, which developed from February to March. This research uses descriptive qualitative method. The subjects used in this study were the principal, teachers and students of SDN 151 Pekanbaru. The data techniques used in this study were interviews and documentation. The result of this research is the School Literacy Program at SDN 151 Pekanbaru, especially grade 4 which consists of several programs such as reading the Qur'an, reading books, libraries, and literacy corners. The role of the teachers in reading through GLS are as guides for students in finding the right reading books, as facilitators by providing services to facilitate the learning process, and as motivator for students in learning. Meanwhile, teachers' role in writing is to train students in creating written works, as a facilitator by giving pleasure to students, and evaluating the results of students' work such as writing poetry activities, rhymes and summary. Keywords: Teacher, Reading and writing, GLS.

Corresponding author:

Email : Virasafitri75@gmail.com

DOI : https://doi.org/10.31004/basicedu.v5i3.938
ISSN 2580-3735 (Media Cetak)

ISSN 2580-1147 (Media Online) 


\section{PENDAHULUAN}

Pada zaman sekarang ini yang semakin pesat menuntut orang untuk memiliki kegemaran dalam membaca dan menulis. Membaca dan menulis menjadi faktor awal dan dasar untuk memasuki dunia pendidikan. Jika seorang anak tidak bisa menulis otomatis dia juga tidak bisa membaca begitu juga sebaliknya. Anak akan merasa kesulitan memahami pelajaran yang diberikan baik di masa sekarang atau pun di masa yang akan datang. Setiap pelaksanaan pembelajaran pasti tidak akan luput dari hambatan-hambatan yang akan dihadapi. Menurut (Suratinah., 2019) Ada hal yang dapat mempengaruhi keberhasilan program Gerakan Literasi ini, yaitu jumlah buku yang ada di perpustakaan sekolah masih sangat terbatas sehingga buku yang ingin siswa baca tidak sesuai dengan seleranya.

Maka dari itu baik dari pemerintah, lingkungan sekolah dan keluarga harus saling bekerja sama, dan saling mendukung dalam kegiatan literasi agar terlaksana dengan baik. Jika hanya satu pihak saja yang menginginkan terwujudnya kegiatan literasi dan tidak ada kolaborasi dengan pihak lain nya, maka tidak akan terlaksana dengan baik kegiatan literasi tersebut. Berdasarkan hasil observasi peneliti pada bulan September 2020 bentuk penerapan Gerakan Literasi Sekolah yang ada di SDN 151 Pekanbaru yaitu kegiatan literasi yang terjadi sebelum pelajaran dimulai, diawali dengan membaca al-qur'an sebagai salah satu bentuk Gerakan Literasi yang ada disekolah tersebut, setelah itu di lanjutkan dengan membaca buku perpustakaan bebas, seperti buku cerita, buku pelajaran, komik dan lain-lain. Gerakan Literasi yang ada di SDN 151 Pekanbaru merupakan kegiatan rutin yang dilaksanakan sebelum memasuki mata pelajaran yang akan dipelajari pada hari itu, kegiatan membaca di sekolah ini biasa dilaksanakan di dalam atau di luar kelas tergantung situasi dan kondisi pada hari itu. Dari hasil wawancara dengan salah satu orang tua siswa kelas 4 SDN 151 Pekanbaru pada bulan September 2020 terdapat permasalahan berkaitan dengan pembelajaran membaca dan menulis melalui GLS ini yaitu kurangnya pembelajaran membaca dan menulis siswa saat di rumah dikarenakan orang tua tidak menjadikan baca tulis sebagai suatu kebiasaan. Maka dari itu guru yang ada di sekolah memiliki peran penting dalam meningkatkan minat baca dan tulis anak karena anak lebih banyak menghabiskan seluruh waktunya di sekolah dari pada di rumah.

Menurut (Hanafi 2019) Guru adalah seseorang yang pekerjaannya sehari-hari mendidik, mengajar dan membimbing peserta didiknya dari yang semula tidak tahu apa-apa menjadi tahu segalanya. Menurut UU No 14 tahun 2005 tentang guru dan dosen (Sadulloh, 2011) Guru adalah sebagai pendidik yang professional dengan tugas utama mendidik, mengajar, membimbing, mengevaluasi peserta didik. Guru juga mempunyai peran-peran penting dalam menjalankan tugasnya. Menurut (Muhammad, 2020) peran guru terdiri atas beberapa yaitu guru sebagai pendidik dan pengajar, guru sebagai mediator atau sumber belajar dan fasilitator, guru sebagai model dan teladan. Menurut (Buan Ludo Afliani Yohana, 2020) Peran guru yaitu sebagai teladan bagi murid nya mulai dari pembiasaan hingga contoh bagaimana guru berpenampilan yang rapi, bertutur kata yang sopan dan juga berperilaku yang baik. Hingga menjadikan siswa rasa ingin mencontoh sebagaiman sikap guru sehingga timbul hal-hal baik yang ingin dicapai.

Di dalam kelas, terjadi proses belajar mengajar antara guru dan siswa. Belajar dan pembelajaran merupakan 2 hal yang berbeda. Menurut (Aflahah, 2019) Belajar merupakan suatu perubahan yang ada di dalam kepribadian siswa yang berupa sikap, kebiasaan, kepandaian atau pengertian. Sedangkan pembelajaran menurut merupakan proses interaksi peserta didik, pendidik dan sumber belajar pada suatu lingkungan belajar tertentu. Lingkungan belajar dapat di temui di sekolah, di bimbingan belajar dll.

Pada saat pembelajaran, ada beberapa indikator yang harus dicapai. Indikator berguna untuk menentukan keberhasilan siswa dalam suatu pembelajaran. menurut (Sobandi, 2016) ada beberapa indikator dalam pembelajaran, yaitu ketertarikan untuk belajar, perhatian belajar, motivasi belajar dan pengetahuan. Sedangkan menurut (Slamet, 2018) ada beberapa indikator dalam pembelajaran, yaitu: Rasa suka/senang, 
pernyataan lebih menyukai, adanya rasa ketertarikan, adanya kesadaran tanpa disuruh, berpartisipasi dalam aktivitas belajar, dan memberikan perhatian.

Saat memasuki dunia pendidikan, membaca dan menulis merupakan faktor awal serta langkah awal seorang anak. Jika seorang anak tidak bisa menulis secara tidak langsung siswa tersebut juga tidak bisa membaca, begitu pula sebaliknya. Menurut (Muhsyanur, 2019) menjelaskan bahwa membaca merupakan proses pencarian informasi menggunakan akal fikiran yang nantinya akan diolah menjadi ilmu pengetahuan sehingga dapat berguna dikehidupan sekarang dan akan datang. Informasi yang didapatkan bisa darimana saja misal, dari buku, internet, orang sekitar dan lain-lain. Sedangkan pengertian menulis menurut (Henry, 2018) merupakan cara seseorang untuk berkomunikasi secara tidak langsung dengan menggunakan bahasa tulis, atau tidak secara tatap muka antara satu dengan yang lain. Berkomunikasi tidak hanya selalu bertatap muka tetapi bisa dengan berbagai media yang ada. Contohnya didalam bentuk tulisan ini, seorang penulis bisa menyampaikan pesan atau curahan hati nya kedalam bentuk tulisan lalu si pembaca memaham maksud dari si penulis tersebut dan juga mendapatkan informasi dari bacaan tersebut.

Kegiatan membaca dan menulis termasuk salah satu trobosan dari pemerintah, trobosan tersebut diberi nama Gerakan Literasi Sekolah. Menurut (Ambar, 2018) Gerakan Literasi Sekolah adalah salah satu langkah untuk membudidayakan kegiatan membaca dan menulis dalam rangka untuk meningkatkan minat baca yang ada di sekolah sehingga akan berdampak pada kemampuan siswa dalam ber literasi sejak dini. Tujuan dari GLS menurut (Nia, 2018) Gerakan Literasi Sekolah dimaksudkan untuk mengajak siswa agar gemar membaca dan meningkatkan keterampilan siswa dalam membaca untuk memperkaya kemampuan.

Gerakan Literasi Siswa ini juga terbagi atas beberapa tahapan. Menurut (Nia, 2018) Terdapat tiga tahap yang ditentukan melalui pedoman yang dikeluarkan oleh Kementrian Pendidikan dan Kebudayaan yakni 1) Tahapan Pembiasaan, 2) Tahap Pengembangan dan 3) Pembiasaan.

Menurut (Harahap Hamjah Mukti, 2017) menjelaskan bahwa ada 3 ruang lingkup dalam GLS, yaitu (a) Lingkungan fisik yang ada disekolah contohnya seperti sarana prasarana literasi. (b) Lingkungan sosial misalnya dukungan dan partisipasi aktif dari seluruh warga sekolah, (c) Lingkungan akademik yaitu program litreasi yang dapat menumbuhkan minat baca dan menunjang kegiatan pembelajaran siswa disekolah.

Menurut (Agustin Sri dkk, 2017) ada beberapa kendala dalam pelaksanaan GLS yaitu: 1) Beberapa warga sekolah masih banyak yang kurang mendukung Gerakan Literasi Sekolah ini dan belum menyadari tanggung jawabanya, 2) Peserta didik memiliki latar belakang yang jauh dari budaya literasi, 3) Unsur penunjang keberhasilan ini adalah perpustakaan yang masih belum lengkap.

\section{METODE PENELITIAN}

Penelitian ini dilakukan di SDN 151 Pekanbaru di Jalan Wonosari, Tangkerang Tengah, Kecamatan Marpoyan Damai, Kota Pekanbaru, Riau. Adapun waktu pelaksanaan penelitian ini yaitu terhitung dari bulan Febuari hingga Maret 2021.

Pendekatan penelitian ini menggunakan pendekatan kualitatif yang bersifat deskriptif. Menurut (Anggito albi dan Setiawan Johan, 2018) penelitian kualitatif adalah "pengumpulan data pada suatu latar belakang ilmiah dengan maksud menafsirkan fenomena yang terjadi dimana peneliti adalah instrument kunci". Menurut (Sugiyono, 2020) Kualitatif adalah jenis penelitian yang digunakan untuk menguji hipotesis dengan data berupa kata-kata, dan juga dapat mengumpulkan serta menganalisis data yang bersifat naratif. 
Prosedur penelitian ini dapat dilihat pada gambar dibawah ini :

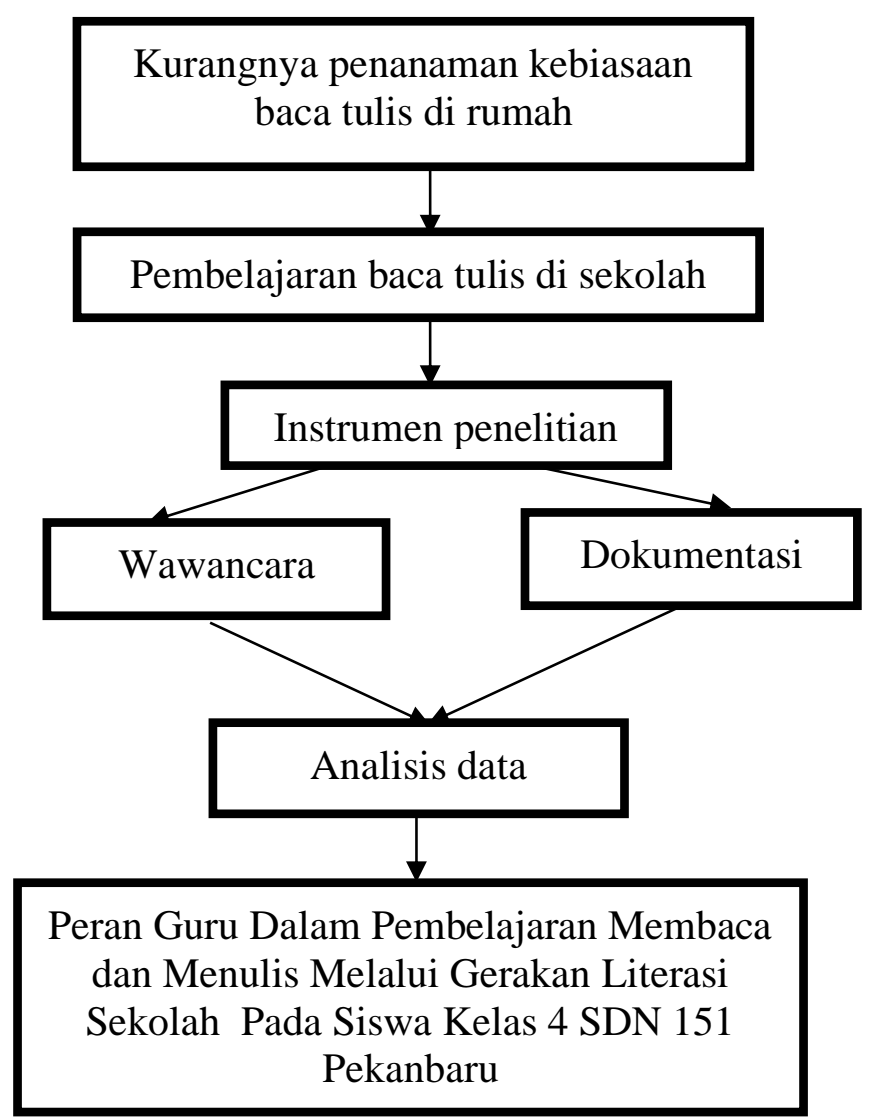

Gambar 1. Prosedur penelitian

Menurut (Ali, 2015) menerangkan bahwa berdasarkan sumbernya, data terbagi menjadi 2 yaitu data primer dan data sekunder. Data primer adalah data yang dikumpulkan atau diperoleh oleh peneliti secara langsung dari sumber datanya. Data sekunder adalah data yang diperoleh atau yang dikumpulkan peneliti dari berbagai sumber yang telah ada.

Data primer dalam penelitian ini adalah data hasil wawancara yang dilakukan kepada guru, siswa dan kepala sekolah disesuaikan sampai kebutuhan penulis terpenuhi. Sedangkan data sekunder adalah dokumentasi. Sumber data dalam penelitian ini yaitu kepala sekolah, guru dan siswa.

Menurut (Sugiyono, 2020) teknik pengumpulan data merupakan langkah yang paling strategis dalam penelitian karena tujuan utama dari penelitian adalah mendapatkan data. Dalam penelitian ini peneliti akan menggunakan 2 teknik pengumpulan data yaitu wawancara dan dokumentasi. Instrumen dalam penelitian ini adalah peneliti sendiri, namun dibantu dengan beberapa instrumen penelitian berupa lembar wawancara, dan pedoman dokumentasi. Dalam penelitian tentunya harus menguji apakah data tersebut absah atau tidaknya.

Teknik analisis data menggunakan triangulasi sumber digunakan untuk menguji kredibilitas data yang dilakukan dengan cara mengecek data yang telah diperoleh melalui berbagai sumber. Uji keabsahan dalam penelitian ini menggunakan uji kredibilitas data menggunakan triangulasi sumber yang bersumber langsung dari guru, siswa dan kepala sekolah kelas 4 SDN 151 Pekanbaru. Dari data yang telat didapat saat melakukan penelitian, selanjutnya data dianalisis menggunakan beberapa teknik. teknik analisis terdiri dari 3 kegiatan yang bersamaan yaitu reduksi data, penyajian data, dan kesimpulan. 
DOI : https://doi.org/10.31004/basicedu.v5i3.938

\section{HASIL DAN PEMBAHASAN}

Gerakan Literasi Sekolah di SDN 151 Pekanbaru dilaksanakan untuk menumbuhkan minat membaca dan menulis siswa sehingga akan berdampak bagi kemampuan siswa. Hal ini sesuai dengan pendapat (Ambar, 2018) Gerakan Literasi Sekolah adalah salah satu langkah untuk membudidayakan kegiatan membaca dan menulis dalam rangka untuk meningkatkan minat baca yang ada di sekolah sehingga akan berdampak pada kemampuan siswa dalam ber literasi sejak dini.

Gerakan Literasi Sekolah di SDN 151 Pekanbaru memiliki penanggung jawab yang dipegang langsung oleh ibu Azwarnidar, S.Pd selaku kepala sekolah. Program Gerakan Literasi Sekolah ini sudah berjalan sekitar 3 tahun yang lalu. Kepala sekolah juga memimpin langsung jalannya GLS di SDN 151 Pekanbaru, sehingga program-program di dalam GLS dapat terlaksana dengan baik.

Pada penelitian ini yang menjadi fokus peneliti adalah kelas 4. Di SDN 151 Pekanbaru kelas 4 terdiri atas 2 gelombang yaitu 4 A dan 4 B. Kelas 4 A dipegang oleh ibu Yusnah, S.Pd dan kelas 4 B dipegang oleh ibu Vopy Susilawati S.Pd. Jumlah masing-masing siswa kelas 4 A dan 4 B yaitu 40 orang setiap kelasnya.

Kelas 4 memiliki jadwal masuk pukul 12.30 WIB. Salah satu cara menjadikan seluruh warga sekolah memiliki budaya literasi yang baik yaitu pihak sekolah bersama-sama membuat program-program berkaitan dengan kegiatan literasi. Berikut adalah program GLS yang berkaitan di kelas 4 SDN 151 Pekanbaru yaitu: (1) Baca Al-quran dilaksanakan oleh seluruh siswa dimulai dari kelas 1-6 termasuk kelas 4. Pada kelas 4 program membaca Al-quran dimulai dari pukul 13.00-13.15 WIB yang dipandu secara langsung oleh wali kelas. Kegiatan membaca Al-quran dilakukan bergantian minimal 3 orang setiap harinya. Masing-masing siswa mendapat satu al-quran, proses membaca al-quran dilakukan dengan sistem sambung ayat. Siswa yang telah selesai membaca, meletakkan kembali Al-quran di pojok kelas dengan rapi. Tujuan membaca Al-quran adalah untuk membentuk karakter siswa sebagai generasi bangsa yang beriman, berilmu dan berakhlak mulia.(2) Selain membaca Al-quran, program GLS di kelas 4 yaitu membaca buku. Kegiatan membaca buku ini berlangsung selama 15 menit dimulai dari jam 13.15-13.30 WIB. Di dalam kelas guru menyediakan pojok baca yang berisi kumpulan buku-buku fiksi dan non fiksi yang telah disesuaikan dengan kesukaan dan minat siswa. Saat membaca buku, guru bertanya mengenai isi buku yang dibaca oleh siswa. Selain bertanya, guru juga memberikan tugas seperti merangkum, menulis puisi, tes membaca memindai dan tanya jawab. Tugas yang diberikan berbeda setiap harinya, disesuaikan pada materi yang dipelajari. Program ini berguna untuk menanamkan kebiasaan membaca buku bagi siswa dan melatih kemampuan siswa dalam menulis dan menangkap informasi-informasi yang terdapat di dalam bacaan tersebut. (3) SDN 151 Pekanbaru juga memiliki perpustakaan untuk mendukung kegiatan literasi. Penanggung jawab perpustakaan di SDN 151 Pekanbaru dipegang oleh bapak Afzufendi Roza, S.H, beliau juga bertugas untuk mengatur buku-buku yang tersedia di perpustakaan. Perpustakaan ini terletak di sudut lapangan. Selain itu, perpustakaan SDN 151 Pekanbaru tidak memiliki daftar kunjungan wajib, tetapi setiap 1 kali seminggu guru-guru akan mengajak siswa ke perpustakaan. Buku-buku yang ada di perpustakaan beraneka ragam, baik buku fiksi seperti buku cerita cinderella, kisah nabi, dll. Pada perpustakaan juga terdapat buku non fiksi seperti buku pelajaran, RPUL, peta, globe, ensiklopedia, buku cetak tema, dll. (4) Program lainnya yang ada di SDN 151 Pekanbaru khususnya pada kelas 4 yaitu Pojok literasi. Di SDN 151 Pekanbaru tersedia 2 pojok literasi yaitu terdapat di dalam dan di luar kelas. Pojok literasi di dalam kelas terletak disudut ruangan di samping lemari. Pojok literasi ini berisi buku bacaan seperti buku fiksi dan buku non fiksi. Manfaat pojok literasi di dalam kelas yaitu untuk memudahkan siswa dalam memperoleh buku bacaan tanpa harus ke perpustakaan. Pojok literasi yang ada di luar kelas terletak di sudut lapangan, dengan penanggung jawab yang dipegang oleh bapak Afzufendi Roza, S.H selaku ketua perpustakaan. Manfaat pojok literasi di luar kelas yaitu dapat mengganti kondisi belajar yang lebih menyenangkan didukung dengan suasana yang sejuk dan nyaman, sehingga siswa betah membaca buku.

Penerapan GLS di SDN 151 Pekanbaru sudah mulai menerapkan kegiatan literasi semaksimal mungkin. Penerapan GLS ini terbukti dengan berjalannya tahapan-tahapan GLS di kelas 4 SDN 151 Pekanbaru yaitu 
tahap pembiasaan dan pengembangan. Hal ini sesuai dengan pendapat Menurut Kemendikbud (2019:29) gerakan literasi sekolah terdiri dari 3 tahap yaitu : 1. Pembiasaan, 2. Pengembangan, 3. Pembelajaran.

Pada tahap pembiasaan, 15 menit sebelum pembelajaran dimulai guru menerapkan membaca buku, dilanjutkan dengan pemberian tugas yang disesuaikan dengan buku bacaan yang siswa baca. Tugas yang diberikan antara lain membaca cepat, membaca memindai, merangkum dan menjawab pertanyaan. Hal ini sesuai dengan pendapat menurut Wahyudi (2020:37) 2 macam teknik dalam membaca yaitu skimming dan scanning.

Peran guru tidak hanya mengajar, tetapi juga membimbing siswa dalam menemukan buku bacaan yang tepat. Di dalam kelas disediakan pojok baca yang berguna untuk memudahkan siswa dalam memperoleh bahan bacaan saat pembelajaran berlangsung, selain itu pojok baca juga dapat menumbuhkan minat membaca di dalam diri siswa. Buku yang tersedia di pojok baca kelas yaitu mulai dari buku fiksi hingga non fiksi. Hal ini sesuai dengan peran guru menurut (Muhammad, 2020) yang terdiri atas beberapa yaitu guru sebagai pendidik dan pengajar, guru sebagai mediator, dan guru sebagai model dan teladan.

Buku bacaan yang di peroleh siswa sudah guru kelompokkan menurut jenis dan kegunaannya masingmasing. Setiap 1 bulan sekali buku-buku yang dibaca siswa akan ditukarkan dan diganti dengan buku yang lebih terkini dan baru, sehingga siswa lebih semangat lagi dalam membaca. Buku-buku tersebut ditukarkan di perpustakaan sekolah. Perpustakaan sekolah juga mengalami pertukaran dengan mendatangkan buku-buku baru minimal 1 tahun sekali. Selain membimbing, peran guru lainnya yaitu sebagai fasilitator. Guru berperan sebagai fasilitator dengan memberikan pelayanan untuk memudahkan siswa dalam kegiatan proses pembelajaran, salah satunya seperti memberikan rasa senang. Memberikan rasa senang bisa guru lakukan dengan berbagai cara seperti menarik perhatian siswa.

Pada saat pembelajaran membaca, guru SDN 151 Pekanbaru menggunakan media untuk menunjang proses pembelajaran lebih menarik, media yang digunakan seperti infokus. Infokus mempunyai ukuran yang lumayan besar menjadikan siswa lebih semangat dalam mengikuti pelajaran. Media infokus juga dapat menampilkan tulisan, gambar dan video. Guru-guru menggunakan infokus dalam pembelajaran membaca karena dapat menampilkan video beserta teks bacaan dibawahnya, sehingga selain melihat tayangan siswa juga dapat membaca. Dengan menggunakan media infokus pembelajaran terlihat lebih hidup dan bervariasi.

Penggunaan infokus hanyalah sarana pendukung untuk menarik perhatian siswa, meskipun buku hanya selembaran kertas tetapi buku adalah gudang ilmu. Buku di SDN 151 Pekanbaru sudah sesuai dengan kriteria buku bacaan yang disukai siswa. Bagi siswa kelas 1-3 mereka suka buku yang berwarna, menarik dan menggunakan bahasa sehari-hari. Siswa kelas 4-6 mereka lebih suka buku yang bermanfaat tetapi tetap dengan menggunakan warna menarik dan bahasa yang mudah dimengerti. Bagi kelas 4 karena masih dari proses penyesuaian, sebagian mereka masih suka buku-buku cerita. Setiap siswa memiliki selera bacaan yang berbeda, untuk itu guru harus menyediakan baik dari buku fiksi hingga non fiksi yang beraneka ragam, sehingga memudahkan siswa dalam mencari bahan bacaan.

Peran guru selanjutnya yaitu memotivasi siswa. Di dalam kelas ada beberapa kegiatan yang guru lakukan untuk menambah motivasi dalam hal belajar termasuk membaca dan menulis. Guru sering menanamkan motivasi di dalam diri siswa berupa kata-kata yaitu "kita tidak boleh lelah dan kita tidak boleh kalah". Motivasi lainnya banyak ditemukan jika siswa sering membaca buku. Saat membaca buku, banyak nilai positif yang dapat siswa ambil. Hal ini sesuai dengan tujuan membaca menurut (Dalman, 2014) adalah untuk mencari dan memperoleh pesan atau memahami makna melalui bacaan, pesan atau informasi yang ada didalam bacaan lah yang nantinya dapat menjadi pengetahuan bagi kita.

Selain menggunakan kata-kata, memotivasi siswa juga bisa dalam bentuk pemberian hadiah atau reward. Guru memberikan reward sebagai tanda bahwa siswa tersebut telah berhasil dalam materi pelajaran hari itu. Pemberian hadiah atau reward bisa dilakukan saat dipertengahan pembelajaran atau diakhir pembelajaran sebagai bentuk evaluasi belajar siswa. 


\section{Peran Guru dalam Pembelajaran Membaca dan Menulis Melalui Gerakan Literasi di Sekolah Dasar - Vira Safitri, Febrina Dafit \\ DOI : https://doi.org/10.31004/basicedu.v5i3.938}

Hal ini sesuai dengan pendapat (Sobandi, 2016) terdapat beberapa indikator dalam pembelajaran yaitu ketertarikan untuk belajar, perhatian belajar, motivasi belajar, dan pengetahuan. Memotivasi siswa dan membangkitkan gairah siswa dalam belajar juga dapat dilakukan dengan bermain games yang menyenangkan. Guru harus pandai dalam mengenali kondisi dimana siswa merasa senang dan bosan sehingga proses pembelajaran berjalan dengan baik. Bagi siswa yang dapat menjawab pertanyaan dari guru akan diberi hadiah berupa peralatan sekolah dan jajanan.

Seorang guru tidak terlepas dari tugas dan tanggung jawab. Tanggung jawab seorang pendidik tidak hanya mengajar dan memberikan nilai, tetapi juga bertanggung jawab untuk membentuk akhlak peserta didik agar mempunyai kepribadian dan tingkah laku yang sesuai dengan nilai-nilai agama dan budaya. Guru sering menanamkan kebiasaan-kebiasaan baik seperti mengucap syukur, membaca doa dan membaca Al-quran.

Membaca buku dan Al-quran di SDN 151 Pekanbaru termasuk salah satu program yang berjalan di kelas 4. Di dalam progam Gerakan Literasi Siswa terdapat 3 tahapan, yaitu pembiasaan, pengembangan dan pembelajaran. Di kelas 4 SDN 151 Pekanbaru, guru-guru hanya menerapkan di tahap pembiasaan dan pengembangan. Guru belum masuk kepada tahap pembelajaran karena kurangnya beberapa persiapan.

Di kelas 4 SDN 151 Pekanbaru, rata-rata siswa lebih menyukai membaca daripada menulis. Siswa yang memilih membaca karena mereka suka mengambil nilai-nilai positif yang ada di dalam bacaan. Membaca juga dapat menambah ilmu dan pengetahuan. Bagi siswa yang memilih menulis karena mereka suka mencurahkan isi fikiran ke dalam bentuk tulisan, selain itu menulis juga dapat menjadikan tulisan lebih rapi dan bagus.

Kegiatan membaca dan menulis merupakan satu kesatuan yang saling berkaitan dan tidak dapat dipisahkan. Membaca dan menulis merupakan keterampilan dasar bagi setiap orang. Jika siswa dapat membaca bacaan, maka siswa itu tidak akan kehabisan ide untuk menulis, dan jika siswa bisa menulis isi fikirannya maka pasti bisa membaca. Pada akhir pembelajaran, guru mengadakan kegiatan evaluasi. Guna evaluasi ini untuk melihat sejauh apa siswa mengerti mengenai materi yang guru jelaskan. Kegiatan evaluasi dapat dilakukan dengan banyak cara salah satunya seperti mengadakan sesi tanya jawab. Setiap siswa diberi peluang untuk bertanya kepada guru nya. Tetapi memang jika dibandingkan kebanyakan siswa yang bertanya adalah siswa yang aktif di dalam kelas.

Kegiatan menulis dapat memberikan banyak manfaat bagi siswa. Menulis dapat melatih kreativitas siswa, siswa juga dapat menuangkan idenya ke dalam bentuk tulisan. Salah satu contoh kegiatan menulis yaitu merangkum isi buku. Kegiatan ini dapat memudahkan siswa dalam menemukan pokok-pokok isi yang penting dalam bacaan. Hal ini sesuai dengan pendapat menurut Sardila (2015:114) menjelaskan bahwa kegiatan menulis bertujuan untuk menyampaikan pesan, berita, informasi kepada pembaca, untuk menata gagasan/ pikiran. Bentuk tulisan tersebut dapat dituangkan dalam buku harian, catatan perkuliahan, catatan rapat, catatan khusus, dan sebagainya.

Selain melatih kreativitas siswa, kegiatan menulis juga membutuhkan motivasi dalam mendorong siswa untuk belajar. Motivasi yang guru berikan yaitu seperti pemberian reward dan juga bermain game yang menyenangkan. Susasana yang menyenangkan dapat meningkatkan daya tarik bagi siswa, sehingga siswa tidak merasa jenuh dan bosan saat pembelajaran berlangsung. Hal ini sesuai dengan pendapat menurut (Vera, 2015) mengemukakan bahwa manfaat menulis yaitu: (1) menulis mengasah kecerdasan, (2) menulis mengembangkan daya inisiatif dan kreativitas, (3) menulis menumbuhkan keberanian, dan (4) menulis mendorong kemauan dan kemampuan mengumpulkan informasi. Beberapa siswa suka dalam menulis dan membaca. Siswa yang suka menulis rata-rata ingin memperindah tulisan nya, sedangkan siswa yang suka membaca ingin memperluas wawasan, memperkaya kosa kata, dan meningkatkan keterampilan menulis. Kegiatan membaca dan menulis merupakan kegiatan yang tidak dapat dipisahkan.

Salah satu peran guru dalam menulis adalah sebagai pembimbing. Guru SDN 151 Pekanbaru membimbing siswa yang akan mengikuti lomba membaca pantun dan puisi. Guru harus bisa membimbing siswa agar dapat tampil dengan maksimal dan percaya diri. Menampilkan pantun dan puisi bukan hanya 
sekedar berdiri diatas panggung, tetapi disesuaikan dengan penilaian yaitu seperti ekspresi wajah, pengucapan, tinggi rendahnya suara, dll.

Selain sebagai pembimbing, guru juga berperan sebagai fasilitator. Salah satu peran guru sebagai fasilitator dalam pembelajaran menulis adalah memberikan rasa yang menyenangkan seperti bermain games. Bermain games juga dapat dilakukan diawal, tengah dan akhir pembelajaran. Permainan games didukung dengan pemberian hadiah sebagai motivasi bagi siswa, seperti alat tulis dan jajanan. Suasana yang menyenangkan tidak hanya dengan bermain games, tetapi dapat menggunakan media. Sarana yang ada di sekolah untuk mendukung kegiatan menulis ini adalah infokus. Penggunaan infokus dapat menarik perhatian siswa dalam belajar. Penggunaan infokus dalam pembelajaran yaitu seperti menayangkan video, lalu siswa mencatat hal-hal penting dalam video tersebut, selain itu siswa juga membuat kesimpulan dari video yang telah ditayangkan.

Setiap siswa pasti memiliki selera yang berbeda dalam memilih bahan bacaan, kebanyakan siswa lebih tertarik dalam memilih buku yang berwarna dan banyak gambar. Menulis bukan hal yang gampang dilakukan sama hal nya seperti membaca. Oleh sebab itu guru harus benar-benar memperhatikan bahan bacaan siswa sehingga siswa lebih termotivasi dalam membaca dan menulis. Kegiatan menulis ini membutuhkan bantuan dari guru. Siswa dapat menulis sendiri dari bacaan yang telah dibacanya melalui membaca, dengan membaca perbendaharaan kata siswa lama-lama akan bertambah dan siswa tidak membutuhkan bantuan guru lagi dalam proses menulis. Tetapi bagi anak yang belum bisa berfikir kreatif maka perlu bantuan dari gurunya.

\section{KESIMPULAN}

Gerakan Literasi Sekolah yang berada di SDN 151 Pekanbaru sudah berjalan cukup baik dengan didukung dengan sarana dan prasarana yang memadai seperti perpustakaan, pojok literasi, pembiasaan literasi yang dilakukan diawal pembelajaran sehingga dapat menumbuh kembangkan budaya literasi baca tulis siwa di sekolah. Program yang terdapat di SDN 151 ini adalah membaca Al-quran 15 menit, membaca buku 15 menit, menyediakan pojok literasi setiap kelasnya, menyediakan perpustakaan yang lengkap dengan beraneka ragam buku fiksi dan non fiksi serta taman baca untuk kegiatan literasi yang berada di luar kelas. Peran guru dalam membaca melalui Gerakan Literasi Siswa yaitu membimbing siswa dalam menemukan buku bacaan yang tepat, sebagai fasilitator dengan memberikan pelayanan untuk memudahkan dalam proses pembelajaran, Sebagai motivator bagi siswa dalam belajar, Peran guru dalam menulis melalui Gerakan Literasi Sekolah, melatih siswa dalam menciptakan suatu karya tulis, sebagai fasilitator dengan memberikan rasa senang pada siswa, m engevaluasi hasil kerja siswa seperti kegiatan menulis puisi, pantun dan meringkas.

\section{UCAPAN TERIMA KASIH}

Penyusunan skripsi ini tidaklah berlangsung segitu saja melainkan penulis banyak memperoleh banyak bantuan dari berbagai pihak berupa saran dan masukan.

\section{DAFTAR PUSTAKA}

Aflahah, M. I. dan. (2019). Konsep Dasar Belajar dan Pembelajaran. Duta Media Publishing.

Agustin Sri dkk. (2017). Gerakan literasi sekolah untuk meningkatkan budaya baca di SMA Negeri 1 Geger. Jurnal Linguista, 1(2), 61-62.

Ali, S. S. dan S. (2015). Dasar Metodologi Penelitian. Literasi Media Publishing.

Ambar, F. G. dan L. W. (2018). Pembudayaan Gerakan Literasi Informasi Siswa Tingkat Sekolah Dasar. 
1364 Peran Guru dalam Pembelajaran Membaca dan Menulis Melalui Gerakan Literasi di Sekolah Dasar - Vira Safitri, Febrina Dafit

DOI : https://doi.org/10.31004/basicedu.v5i3.938

Jurnal Edulib, 8(2), 172.

Anggito albi dan Setiawan Johan. (2018). Metodologi Penelitian Kualitatif.

Buan Ludo Afliani Yohana. (2020). Guru dan Pendidikan Karakter. Penerbit Adab.

Dalman. (2014). Keterampilan Membaca. PT Raja Grafindo Persada.

Hanafi Halid dan Muzakir. (2019). Profesionalisme Guru Dalam Pengelolaan Kegiatan Pembelajaran Di Sekolah. Deepublish.

Harahap Hamjah Mukti, D. (2017). Pengembangan Program Literasi Sekolah Untuk Meningkatkan Kualitas Pendidikan Dasar Tingkat Sekolah Menengah Pertama Negeri Kota Medan. Jurnal Pembangunan Perkotaan, 1(2), 30-31.

Henry, T. G. (2018). Menulis Sebagai Suatu Keterampilan Berbahasa. Penerbit Angkasa.

Muhammad, M. S. dan A. (2020). Peran Guru, Orang Tua, Metode dan Media Pembelajaran: Strategi KBM di Masa Pandemi Covid-19. Penerbit 3M Media Karya.

Muhsyanur. (n.d.). Pengembangan Keterampilan Membaca Suatu Keterampilan Berbahasa Reseptif. In 2019. CV. Buginese Art.

Nia, H. S. dan L. A. (2018). Gerakan Literasi Sekolah: Implementasi Tahap Pembiasaan dan Pengembangan Literasi Di SD Sukorejo Kediri. Jurnal Basa Taka, 1(2), 30-31.

Sadulloh Uyoh. (2011). Pedagogik (Ilmu Mendidik). Penerbit Alfabeta.

Slamet, R. (2018). Hubungan Minat Belajar Siswa Dengan Prestasi Belajar Belajar Siswa Pada Mata Pelajaran Kimia Di SMA Negeri 1 Tebat Karai dan SMA Negeri 1 Kabupaten Kepahiang. 2(1), 79-80.

Sobandi, N. S. dan. (2016). Minat Belajar Sebagai Determinan Hasil Belajar Siswa. 1(1), 130.

Sugiyono. (2020). Metode Penelitian Kualitatif. Penerbit Alfabeta.

Suratinah., Y. T. I. dan. (2019). Implementasi Gerakan Literasi Sekolah Di Sekolah Dasar Dharma Karya Universitas Terbuka. Jurnal Ilmiah Sekolah Dasar, 3(4), 49.

Vera, S. (2015). Strategi Pengembangan Linguistik Terapan Melalui Kemampuan Menulis Biografi dan Autobiografi: Sebuah Upaya Membangun Keterampilan Menulis Kreatif Mahasiswa. Jurnal Pemikiran Islam, 40(2), 114-115. 